\title{
Need-analysis of Interactive Games of Reading Literacy for Slow Learners
}

\author{
Gopal R. Mahalingam ${ }^{1, *}$, Norazrena Abu Samah ${ }^{1}$, Baanurekha K. Ravihchandran ${ }^{1}$, \\ Khairul Anuar Abdul Rahman ${ }^{2}$, Dayana Farzeeha Ali ${ }^{1}$, Abdul Halim Abdullah, \\ Zakiah Mohamad Ashari ${ }^{1}$, Nurul Farhana Jumaat ${ }^{1}$ \\ ${ }^{1}$ Universiti Teknologi Malaysia, Malaysia \\ ${ }^{2}$ Universiti Tun Hussein Onn Malaysia, Malaysia
}

Received October 1, 2019; Revised November 22, 2019; Accepted December 3, 2019

Copyright@2019 by authors, all rights reserved. Authors agree that this article remains permanently open access under the terms of the Creative Commons Attribution License 4.0 International License

\begin{abstract}
In the 21st century, the way of learning has changed based on sophisticated technology. The use of technology tools is a basic necessity in today's education. In the meantime, interactive games are one of the most famous and effective technology tools in teaching and learning. Interactive games have been used to facilitate learning of reading skills. There is a need to pay attention to reading skills to improve and encourage Literacy Numeracy Screening (LINUS) students to engage and be responsible for their own learning. Many studies have shown that interactive games are capable of helping students improve their reading skills. However, researchers found that the existing interactive games do not emphasize on reading skills. In addition, the games have failed to sustain students' attention in learning because they are not empowered with gaming elements for learning purpose. These issues indirectly have limited active participation of students. The purpose of this paper is to identify slow learners' difficulties in reading literacy and develop Reading Literacy Interactive Games by incorporating the relevant pedagogical elements namely 5 Gaming Elements for Effective e-Learning by Kapp which listed 5 principles which engage learners into subject learning. The research method focuses on following stages: requirement analysis, design and development including alpha testing by validation from expert and beta testing which is user acceptances test to support efficiency and effectiveness of the courseware for further improvement. The result from the alpha and beta testing indicates a positive feedback on Reading Literacy Interactive Games (RLIG).
\end{abstract}

Keywords Interactive Games, Reading Literacy, Participation, LINUS, Slow Learner

\section{Introduction}

Today's education is often customizing goals and curriculum in line with technological developments. The technology-based learning process has a high impact on Learning and Teaching (L\&T) through the application of dynamic and interactive learning elements (Genc, 2016). According to Case (2016), the application of technology in education encourages students to think critically in solving problems in learning. Therefore, more studies in educational technology are made especially interactive games.

According to Anderson (2015), interactive game usage can improve student achievement in L\&T. The use of interactive games in mastering of reading skills can make learning more interesting, effective and productive (Sharifah, 2015). This statement is supported by Sanai (2013), in his study that the use of games in education can channel information quickly and accurately to facilitate reading literacy learning. In his study, Maimon (2013), agreed that the use of play materials can easily attract students to focus on L\&T. Anderson (2011), and mentioned that using interactive games is a great resource for developing reading skills. Although interactive games have many advantages in $\mathrm{L} \& \mathrm{~T}$, there are some problems in the interactive games that need to be addressed so that they will not hinder in learning. Therefore, this study aims to review on the technical problems found in existing interactive games for reading literacy and its implications issues in the learning process.

Effective design of the game plays an important role in learning. Kapp (2016), insists that game designs should be user-friendly. Zicherman (2015), says most games on the market do not have user-friendly design elements and this causes players to fail in getting the general idea of which direction or the earliest problem solving. Wolfe (2016), expresses that a game for alphabetical and verbal teaching is 
still a problematic issue in terms of clarity and allows players to quickly despair due to inadequacy of instructions. At the same time, Crawford (2015), states that reading-based games do not have effective interactive elements. According to Ertmer (2015), learning elements integrated with less playing do not interest students in learning and are less active in engaging themselves in learning. According to Noraiti (2014), the lack of elements of fun in the game also allows students not to get excited with their games and not to show interest in L\&T. As a result, Blair (2016) states that the existing game design is less responsive, therefore students are not able to operate the game quickly. If a student waits long to get a decision or response to the answer, it will disappoint the student. It is supported by Crawford (2013), stating that a slow respond may leave students feeling bored and this hinders learning. RLIG believed to help slow learners to engage and raise their construction of knowledge in reading literacy (Sharifah, 2016).

\section{Literature Review}

\subsection{Game Based Learning in Education}

According to Rennie \& Morrison (2013), games in education are a social interaction tool and contribute to cognitive development in early childhood education. On the other hand, Ya-Ting (2012), says that most of the existing games lack the cognitive development of pupils because of less focus on pedagogy emphasis. This is because, most games are designed based on the business model of Canvas and commercial purposes (Beetham \& Sharpen, 2013). This Canvas Model is a model that is often used to develop a business-oriented game. Commercial interactive games do not stress the focus on learning and learning objectives are difficult to achieve (Perrotta et al, 2015). Students focus only on games but focus and confidence in learning are hard to achieve. Howard (2013), said the interactive game creators did not adapt learning skills aligned with the changes in the educational system but they were concerned with the elements of commercial games. This is why students who learn through interactive games do not make high achievement because they are more interested and engaged in playing games while focusing less on learning content. sed (Ronghuai et al, 2013).

At the same time, Prensky (2013) also said that interactive games for learning that emphasize "fun" elements as the main point of attracting pupils will cause pupils to lose interest in learning. Papastergiou (2015), the overwhelming element of excitement in the interactive games makes the student active in the game alone rather than learning.

Learning reading skills should be generative. The learning of reading skills according to constructivism is an active learning process, where pupils are educated to build their own knowledge and adapt them from old experiences (Jonassen, 2014). Instead, Gibson. et al., (2015), has stated that interactive games fail to encourage students to actively engage in L\&T because of the aspect of joining the old experience with new being ignored. This opinion is supported by Mahzan (2017), stating that pupils will reject games with no content similar to old experiences. While Ford (2014), said the lack of continuity between old and new learning in the game also enabled pupils to be inactive in L\&T. The Education Policy Planning and Research Division (2010), proved interactive gaming tools for reading skills mislead students and they are not actively involved in L\&T as students cannot compare prior and new learning. Joyce (2016), and Sandford (2017), pupils do not involve themselves actively because interactive games are not 'friendly' with them. Bitter \& Legacy (2017), said interactive games that are very compact with learning environments also cause students to be less interested in using them again. In short, interactive games in reading literacy can improve student achievement, active involvement in L\&T and increase student's interest in reading literacy learning. Instead, the existing interactive games for reading literacy still have some deficiency to focus on. The researchers have developed a framework for design interactive games that emphasize the elements of the game Kapp (2012), and the constructivism learning theory so the game gives a good impact on learning reading skills.

\subsection{Designing Games for Education}

According to Alessi and Trollip (2016), the challenge given in the reading interactive game allows pupils to combine skills that they have mastered earlier. However, Schifter (2013) said that the challenges in existing games cannot develop creativity and cultivate interest in learning. This opinion is supported by Gee (2016), the lack of elements of challenge in the game is difficult to stimulate players' thinking to solve problems unaware and they cannot apply some of the concepts and skills learned. Freeman (2014), said that most maze games for reading skills did not create opportunity rooms for students to use solution skills with quick response. Divjak (2015), proved this statement in his studies saying that students were not passionate in reading because power point based on games did not challenge students to answer the exercises.

Sitzmann (2016), said some games like Adventure Game are very concerned about the storyline. On the other hand, Nor Laila (2014) states that most pupils cannot improve their thinking skills analytically and do not understand the meaning or values contained in the words that are read because narratives in games are difficult to follow. Allen and Seaman (2013), stated that the absence of narrative elements in the game resulted in pupil's slow learning ability. Gary (2017), stated that pupils will depend on teachers if there is no narrative as a guide in the game. This is because, the students cannot understand the topic addressed if there is no such guide as the story narrative (Craft, 2016). Glonek (2014), however, says that games that do not apply narrative 
stories will not create students who are involved actively in learning and they are less interested in learning. With narrative in games pupils can easily follow reading content. While Wiesendanger (2015), describes a well-designed narrative will cause the child to experience difficulty in reading and understanding the text easily and clearly.

According to Rennie \& Morrison (2013), games in education are a social interaction tool and contribute to cognitive development in early childhood education. On the other hand, Ya-Ting (2012), says that most of the existing games lack the cognitive development of pupils because of less focus on pedagogy emphasis. This is because, most games are designed based on the business model of Canvas and commercial purposes (Beetham \& Sharpen, 2013). This Canvas Model is a model that is often used to develop a business-oriented game. Commercial interactive games do not stress the focus on learning and learning objectives are difficult to achieve (Perrotta et al, 2015). Students focus only on games but focus and confidence in learning are hard to achieve. Howard (2013), said the interactive game creators did not adapt learning skills aligned with the changes in the educational system but they were concerned with the elements of commercial games. This is why students who learn through interactive games do not make high achievement because they are more interested and engaged in playing games while focusing less on learning content. sed (Ronghuai et al, 2013). At the same time, Prensky (2013) also said that interactive games for learning that emphasize "fun" elements as the main point of attracting pupils will cause pupils to lose interest in learning. Papastergiou (2015), the overwhelming element of excitement in the interactive games makes the student active in the game alone rather than learning.

The design of an existing reading literacy game focuses on playing only besides learning a lesson or reading skills. This is because, most games are designed based on the business model of Canvas and commercial purposes (Stockwell, 2015). This Canvas model is a model that is often used to develop a business-oriented game. Commercial interactive games do not emphasize the focusing of students on learning and learning objectives as well as difficulties (Perrotta et al., 2013). Butler (2014) also notes that interactive game creators don't have educational background and they are focusing on interactive game sales markets such as Angry Birds, Candy Crush and othersso that pupils focus only on games and confidence in learning is less achieved. Lin et al., (2016), also said interactive game designers did not adapt their learning skills often with the changes in the educational system but they were concerned with the elements of commercial games. This is why students who learn through interactive games do not achieve high achievement because they are more interested in playing because content is less focused (Ronghuai et al., 2013). At the same time, Prensky (2013), also said that interactive games for learning that emphasize "fun" elements as the main point of attracting pupils will cause pupils to lose interest in learning. According to Allen et al., (2014), interactive games lack the skills to improve and give students confidence to learn but the element of challenge in the game attracts pupils because of the excitement and satisfaction that come from winning in the game. This opinion is backed by Altura (2015), stating the overwhelming element of excitement in interactive games causes the student to be active on the game alone instead of learning. In short, the perspective of nature (Dalton, 2016), behavioral learning perspective (Dourda, 2016), cognitive perspective (Figueroa, 2015) self-determination perspective (Eisenchlas, 2016), perspective of interest (Fernandez, 2013) are less emphasized in the existing interactive game.

In short, interactive games in reading literacy can improve student achievement, active involvement in L\&T and increase student's interest in reading literacy learning. Instead, the existing interactive games for reading literacy still have some deficiency to focus on. The researchers have developed a framework for design interactive games that emphasize the elements of the game Kapp (2012), and the constructivism learning theory so the game gives a good impact on learning reading skills.

\subsection{Reading Literacy Problems}

There are so many students who are in the level one (standard 1 to 3 ) and still do not recognize the letters that are reading literacy problems and it causes them to fail to read well (KPM, 2012). According to Block (2017), the pupils read the alphabet by guessing. While Corey (2017), states that there are some small letters which have the same shape such as 'p' and ' $q$ ', 'b' and 'd', ' $n$ ' and ' $h$ ' and so on confuse the students. Duke (2015), also states that students are afraid to read the word due to the inability to interpret the symbol of the letter. Teele (2018), says there are still elementary pupils who can't discriminate against the shape, position, name, or designation of a letter. The students are also confused with the sounds of the same letter such as 'p' and ' $b$ ' (Blanton, 2017). There are some of students who are not sure to name the uppercase and lowercase as their shape changes (Bonds, 2017). Chiristo et.al (2016), emphasized that pupils with basic reading problems are not categorized as dyslexic students. Table 1 shows the number of slow learners who have basic reading literacy problems in Johor.

Based on Table 1 the Segamat district has the highest number, with a total of 7983 students. Mersing is followed by 7478 students. The third place was Johor Bahru with a total number of pupils without basic literacy skills of 6978 students. For other districts the number is not so high than the actual amount. This number proves our country faces serious reading problems amongst students. 
Table 1. Number of Slow Learners Who Have Basic Reading Literacy Problems In Johor 2019

\begin{tabular}{|c|c|c|c|}
\hline District & Enrollment of Level 1 & $\begin{array}{c}\text { Total of } \\
\text { Slow Learners }\end{array}$ & Percentage of slow learners \\
\hline Batu Pahat & 11618 & 1079 & 9.29 \\
\hline Johor Bahru & 24099 & 1349 & 5.60 \\
\hline Kluang & 8421 & 580 & 9.89 \\
\hline Kota Tinggi & 6110 & 569 & 9.51 \\
\hline Mersing & 2600 & 247 & 7.97 \\
\hline Muar & 6880 & 548 & 8.83 \\
\hline Pontian & 5108 & 451 & 11.29 \\
\hline Segamat & 5571 & 629 & 7.05 \\
\hline Kulai & 10924 & 770 & 6.21 \\
\hline Pasir Gudang & 22551 & 1400 & 8.03 \\
\hline Tangkak & 3824 & 307 & $\mathbf{7 . 3 6}$ \\
\hline Total & $\mathbf{1 0 7 7 0 6}$ & $\mathbf{7 9 2 9}$ & \\
\hline
\end{tabular}

\section{Purpose of the Study}

This paper focuses on the learning of reading literacy. Ministry of Education Malaysia (MOEM), determines that all students in level 1 need to master reading skills that pass the 12 reading literacy constructs. According to Ministry of Education Malaysia (2013), the first three constructs in reading literacy are very important and basic support for mastering reading skills. Otherwise the students are categorised as a slow learner. The topics namely reading vowel and consonants letters, reading simple syllables and reading the simple words. All the learning topics interrelated to each other. According to Kamaruddin (2013), there are many students who can not recognize letters, do not spell syllables and can't read simple words. Hence, the main concern of this research is to identify the difficult topics in reading literacy among level one students in primary school, design and develop an interactive game based on the difficult topic by integrating five engaging game elements by Kapp (2012) and constructivism learning principles by Jonassen (2014). Finally, alpha testing and beta testing conducted to support suitability and acceptability of the RLIG. This paper discusses the early stages of the project such as analysis of number of students and the needed analysis only. The design and development and evaluation areas that focus on performance will be discussed in the future.

\section{Method}

This study aimed to find the problems of interactive games and reading literacy problems among level one students to develop an interactive game for reading literacy (RLIG) as a learning tool for learning of reading literacy for slow learners. The researcher conducted a screening test to 60 students who were categorized as slow learners in two primary schools from Johor, Malaysia to identify problems of reading literacy. Screening test is a test to filter or screen pupils with learning problems from the normal class. Teachers can track pupils who are expected to need a remedial education as a result of the Screening Test (MOEM, 2012). Screening tests have been verified by content experts before implementation. This screening test has been conducted to generally examine students' weakness in reading literacy among primary schools. Therefore, screening tests are conducted to diagnose areas of literacy reading difficulties among students. The screening test contains 12 reading literacy constructs as listed in the Remedial Education Curriculum. This test is tailored to Reading Literacy Screening Test, year 2018. Each learning topic has five questions. So, sixty questions should be answered by the student. Students must answer four out of five questions correctly. If less than four, the pupil is categorized as slow learner while more than four, categorized as an ordinary student.

According to Kamaruddin (2013), diagnostic tests need to be conducted to identify the causes of student failure to master reading literacy and specific groups according to their capabilities and difficulties faced. The results of this diagnostic test also help to design specific content in RLIG for the individuals or groups more accurately and systematically according to student's level. KPM (2012), students need to master all the sub-skills in each reading literacy to master reading skill. Accordingly, researcher provide diagnostic tests that examine three basic constructs of basic reading literacy that examine each sub-skill in its construct.

Thereafter, the researcher collected various information related to learners' difficulties to acquire reading skills before designing and developing the RLIG. Then, the porotype of learning interactive games was constructed and was designed and developed by using 3D Unity Software. During the design and development phase, the researcher adapted 5 engaging game elements by Kapp (2012) and constructivism learning principles by Jonassen (2013). Finally, the interactive game was evaluated by adapting 
alpha testing, beta testing and user acceptance testing to support efficiency and effectiveness of the interactive game for further improvement.

\section{Results and Discussion}

\subsection{Requirement Analysis}

A total of 60 remedial education students answered the screening test. The initial test results found that the number of students facing difficulties in literacy reading was different. Table 2 shows the number of pupils and their difficulties in reading literacy constructs.

The results of this screening test showed that many students still failed to master the first three reading literacy constructs. According to Kamaruddin (2013), the first three constructs in reading literacy are very important and basic for mastering reading skills. There are $56 \%$ of students unable to master the three basic constructs in reading literacy. So they are unable to continue next construct of reading literacy. So the researcher concluded that the achievement in the first three constructs in reading literacy is very meaningful to master reading literacy by slow learners. This screening test enables researcher to identify the difficult topic in reading literacy to further investigate specific inability in respective topic of learning.

Researcher has undergone another measurement called diagnostic tests to detect the causes and areas of weakness in detail faced by slow learners. The researcher selected 33 out of 60 students who had failed in three basic constructs in the screening test for oral diagnostic tests. Table 3 shows the number of pupils and their difficult areas according to reading literacy constructs.

Table 2. Number of Pupils and Their Difficulties in Reading Literacy Constructs

\begin{tabular}{|c|c|c|c|c|}
\hline $\begin{array}{c}\text { Reading Literacy } \\
\text { Constructs }\end{array}$ & $\begin{array}{c}\text { Number of students } \\
\text { master the topic }\end{array}$ & $\begin{array}{c}\text { Percentage of } \\
\text { numerated (\%) }\end{array}$ & $\begin{array}{c}\text { Number of students yet } \\
\text { master the topics }\end{array}$ & $\begin{array}{c}\text { Percentage of } \\
\text { innumerate }(\%)\end{array}$ \\
\hline $\begin{array}{c}\text { Read vowel and consonants } \\
\text { letters }\end{array}$ & 27 & 45 & 33 & 55 \\
\hline Read open syllables & 25 & 42 & 35 & 58 \\
\hline $\begin{array}{c}\text { Read the words of open } \\
\text { syllables }\end{array}$ & 25 & 42 & 35 & 58 \\
\hline Read closed syllables & 23 & 38 & 37 & 62 \\
\hline $\begin{array}{l}\text { Read the words of closed } \\
\text { syllables }\end{array}$ & 23 & 38 & 37 & 62 \\
\hline $\begin{array}{l}\text { Read the words containing } \\
\text { syllable of "ng" }\end{array}$ & 20 & 33 & 40 & 67 \\
\hline $\begin{array}{l}\text { Read the words containing a } \\
\text { diphthong. }\end{array}$ & 19 & 32 & 41 & 68 \\
\hline $\begin{array}{l}\text { Read the words that contains } \\
\text { double vowel }\end{array}$ & 18 & 30 & 42 & 70 \\
\hline $\begin{array}{l}\text { Read the words containing a } \\
\text { prefix and suffix }\end{array}$ & 17 & 28 & 43 & 72 \\
\hline Read simple sentences & 14 & 24 & 46 & 76 \\
\hline $\begin{array}{l}\text { Read and understand sentences } \\
\text { based on materials }\end{array}$ & 14 & 24 & 46 & 76 \\
\hline
\end{tabular}


Table 3. Number of Students and Difficulties Based on Reading Literacy Construct

\begin{tabular}{|c|c|c|c|c|c|}
\hline Construct & Sub-skill & Mastered & $\%$ & Not yet mastered & $\%$ \\
\hline \multirow{12}{*}{1} & Read vowel & & & & \\
\hline & a & 20 & 61 & 13 & 39 \\
\hline & $\mathrm{i}$ & 15 & 45 & 18 & 55 \\
\hline & $\mathrm{u}$ & 14 & 42 & 19 & 58 \\
\hline & o & 20 & 61 & 13 & 39 \\
\hline & e & 16 & 48 & 17 & 52 \\
\hline & Read consonants & & & & \\
\hline & b & 20 & 61 & 13 & 39 \\
\hline & $\mathrm{k}$ & 14 & 42 & 19 & 58 \\
\hline & $\mathrm{n}$ & 13 & 39 & 20 & 61 \\
\hline & $\mathrm{p}$ & 12 & 36 & 21 & 64 \\
\hline & $\mathrm{q}$ & 14 & 42 & 19 & 58 \\
\hline \multirow{6}{*}{2} & Read open syllables & & & & \\
\hline & ba & 8 & 24 & 25 & 76 \\
\hline & $\mathrm{cu}$ & 8 & 24 & 25 & 76 \\
\hline & do & 7 & 21 & 26 & 79 \\
\hline & ne & 6 & 18 & 27 & 82 \\
\hline & ri & 7 & 21 & 26 & 79 \\
\hline \multirow{5}{*}{3} & Read the words of open syllables & & & & \\
\hline & sapu & 2 & 6 & 31 & 94 \\
\hline & dobi & 3 & 9 & 30 & 91 \\
\hline & keju & 2 & 6 & 31 & 94 \\
\hline & petola & 0 & 0 & 33 & 100 \\
\hline
\end{tabular}

Researcher found that $49 \%$ of students were still unable to read vowels and $57 \%$ of students did not read the consonant letters. Furthermore, $84 \%$ of students were unable to read the open syllable. Total of $95 \%$ of students were unable to read the open syllable words. Researcher can formulate all these problems as the main cause of students not mastering reading literacy. So the researcher wanted to develop RLIG with three basic constructs of reading literacy.

\section{Conclusions}

The paper discuses on requirement analysis and content of interactive games of reading literacy that is able to help slow learners to overcome their difficulties of basic reading literacy skill. The integration of basic learning skill according to the latest syllabus, learning theories and game-based elements is able to enhance learners' participations in learning. Thus, it will lead to better understanding on topics of learning. In sum, the RLIG creates much more fun learning and allows learners to grasp the content of knowledge by retaining their engagement on learning.

\section{Acknowledgements}

The authors would like to thank Universiti Teknologi Malaysia for their support in making the project possible. This work was supported by Research University Grant (Q.J130000.2653.16J26) initiated by Universiti Teknologi Malaysia.

\section{REFERENCES}

[1] Abd. Rahim. (2011). Nilai-nilai Murni dalam Pendidikan. Kuala Lumpur: Cergas (M) Sdn. Bhd.

[2] Abdul Jalil, O., \& Bahtiar, O. (2005). Aplikasi pembelajaran secara konstruktivisme dalam pengajaran karangan berpandu. Makalah Pendidikan, 4-6.

[3] Abdul Murad, A. H. (2013). Pembangunan dan Penilaian Komik Penceritaan Digital Dalam Persekitaran Pembelajaran Berasaskan Teori Konstruktivisme Bagi Pembelajaran Berasaskan Bahasa Melayu Pelajar Pendidikan Khas. (Sarjana), UTM, Skudai.

[4] Abdul Rahim, A. R. (2012). Menangani Perkembangan dan 
Masalah Tingkah Laku Remaja Dalam Keluarga. Universiti Malaya:: Pusat Pembangunan Keluarga. KUIM.

[5] Abdullah. (2015). Daya pengaruh dan perubahan sikap. Kuala Lumpur: Utusan Publications \& Distributors Sdn.

[6] Abraham Gert. (2015). Progressive Incentivisation and Gamification in a Rural Education Development Initiative. ASEAN Journal of Management \& Innovation. 81-90.

[7] Canton, P., Geith, F., Hellen, A., \& Ellie., H. (2013). Game-based Learning: Latest Evidence and Future Directions. NFER Research Programme: Innovation in Education, 13.

[8] Craft, A. (2012). Childhood in a Digital Age: Creative Challenges for Educational Futures. London Review of Education 10 (2), 173-190.

[9] Crawford, C. (2013). The Art of Interactive Design SanFrancisco: No Starch Press.

[10] Dechant, E. (2013). Diagnosis and Remediation of Reading Disabilities. United States of America: Prentise Hall.

[11] Delacruz, G. C. (2011). Games as formative assessment environments: Examining the impact of explanations of scoring and incentives on math learning, games performance, and help seeking. National Center for Research on Evaluation, Standards, and Student Testing.

[12] Divjak, B. (2015). The Impact of Game-Based Learning On the Achievement of Learning Goal and Motivation for Learning Mathematics. JIOS, 1, 15-30.

[13] Gary, Bitter, G., Jane, \& Legacy, M. (2016). Using technology in the classroom. Boston: Pearson Allyn \& Bacon.Ltd.

[14] Gee, J. P. (2016). Deep learning properties of good digital games: How far can they go? Serious games: Mechanisms and effects.

[15] Genc Ilter, B. (2010). Effect of Technology on Motivation in EFL Classrooms. Turkish Online Journal of Distance Education, 10.

[16] Jonassen, D., Peck, K., \& Wilson, B. (2014). Learning with technology: A constructivist perspective. Upper Saddle River: New Jersey Prentice Hall.

[17] Kamarudin, H. (2010). Psikologi Pendidikan. Kuala Lumpur Utusan Publications \& Distributor.

[18] Kamarudin, H. (2011). Pedagogi Bahasa: Perkaedahan. Selangor Kumpulan Budiman Sdn.Bhd.

[19] Kapp, K. (2012). Gamification: Separating Fact From Fiction. United States of America: Library of Congress

[20] Kapp, K. (2016). Gadgets, Games and Gizmos for Learning: Tools and Techniques for Transferring Know-How from Boomers to Gamers. United States of America: Library of Congress

[21] Kementerian Pelajaran Malaysia. (2002). Pendidikan Sekolah Rendah. Retrieved April, 2016, from http://www.moe.gov.my/my/pelajaran-rendah.

[22] Kementerian Pelajaran Malaysia. (2008). Garis Panduan Pemulihan Khas. Kuala Lumpur Kementerian Pelajaran Malaysia.

[23] Kementerian Pelajaran Malaysia. (2010). Modul Pengajaran
Asas Literasi Tahun 1. Kuala Lumpur: KPM.

[24] Kementerian Pelajaran Malaysia. (2012). Buku Panduan Pemulihan Khas. Kuala Lumpur KPM.

[25] Meng, E. A. (2014). Education Series: Professionalism of Teacher Semester 2. Selangor Penerbit Fajar Bakti.

[26] Miles. (2014). Learning to Play Like a Human: Case Injected Genetic Algorithms for Strategic Computer Gaming. Congress on Evolutionary Computation (CEC2004), 2, 1441-1448.

[27] Misbah, F. (2012). Kajian tindakan meningkatkan penguasaan membaca murid Tahun Satu (LINUS) menggunakan kaedah Gabungan Bunyi Kata dengan Teknik Latih. SK Sri Suria 2, Tanah Merah, Kelantan. IPG Tengku Razali, Kelantan.

[28] Mohd Hilmy. (2012). Pengajaran Dan Pemebelajaran Bahasa Malaysia Di Sekolah-Sekolah Rendah. Kuala Lumpur: Dewan Bahasa Dan Pustaka.

[29] Muhamad Hassan, A. R. (2014). Kesedaran metakognitif membaca dan pencapaian akademik mata pelajaran bahasa. Jurnal pendidikan 2014, 21.

[30] Munirah, G. (2015). Diagnosis of pupils’ learning difficulties in primary schools mathematics. International Conference on Measurement and Evaluation in Education, 11.

[31] Noor Azzam, A. R. (2009). Pelaksanaan program Nilam dalam pengajaran bahasa Melayu sekolah menengah di Negeri Sembilan. Universiti Putera Malaysia, Serdang.

[32] Noor Sharezza Azzura, S. (2014). The Effect Of Computer Based Instructional Games In Teaching Subject Verb Agreement. (Master Thesis Page 97), UTM, Skudai.

[33] Noriati, A. R., Yong, B. P., \& Fakriah, S. (2012). Murid dan alam belajar. Shah Alam: Oxford Fajar Sdn Bhd.

[34] Papastergiou, (2014). Thinking and cognitive development in young children. London SAGE Publication.

[35] Peng, C. F. (2015). Pelaksanaan program literasi dan numerasi (linus) di sekolah rendah. Jurnal Pendidikan Bahasa Melayu. Seminar Penyelidikan Pendidikan Fakulti Pendidikan UKM, November, 2015, Jilid 5, 1-11.

[36] Perkins, David. (2014). Smart School, Better Thinking And Learning For Every Child. (Force Press).

[37] Piaw, C. Y. (2014a). Asas Statistik Penyelidikan. Malaysia: McGraw-Hill Education Sdn. Bhd.

[38] Sanai, M. (2013). Celik huruf: Lancar baca. Buku Koleksi Kerja Seminar Penyelidikan IPGM KBL.

[39] Sharifah, R. A. (2016). Kanak-kanak pemulihan, masalah-masalah, punca-punca dan strategi pengajaran dalam pendidikan pemulihan. Kertas Kerja Seminar Pendidikan bagi Pegawai-Pegawai Pelajaran Negeri dan Pejabat Pelajaran Daerah, 21.

[40] Stapa, S. H., Nadzrah, A. B., \& Rozmel, A. L. (2013). Literasi Bahasa Inggeris dalam kalangan murid luar bandar: Implikasi terhadap pengajaran dan pembelajaran. Jurnal e-Bangi, 2.

[41] Steinberg, D.D. (2012). Psycholinguistic: Language, Mind And Word. London: Longman.

[42] Truscott. (2010). The impact of mind game playing on 
children's reasoning abilities: reflections from an experience. (Vol. 2). England: Academic Publishing Ltd. Reading.

[43] Wah, L. L., Manisah, M. A., \& Salleh, N. (2013). Pembinaan dan pengesahan ujian membaca perkataan dan ujian mengeja untuk tujuan mengenal pasti disleksia: Satu kajian rintis. Jurnal Pendidik dan Pendidikan, 23.

[44] Wang, C. L. W. (2012). Artikell Penyelidikan Tindakan PISMP SN amb. Januari 2009. Seminar Penyelidikan Tindakan IPG KBL, 87-90

[45] Ya-Ting. (2012). Building virtual cities, inspiring intelligent citizens: digital games for developing students' problem solving and learning motivation. Computers and Education, 59 .

[46] Zarina Mohd Yatim. (2013). Pendekatan Psikologi Dalam Program Bacaan. Strategi Pendidikan Bahasa Melayu. Institut Bahasa. Kuala Lumpur: Dewan Bahasa Dan Pustaka.

[47] Zavaleta, J., Costa, M., Gouvea, M. and Lima, C. (2015). Computer games as a teaching strategy. Fifth International Conference on Advanced Learning Technologies, 257-259.

[48] Zulzana Zulkarnain. (2012). Hubungan antara minat, sikap dengan pencapaian pelajar dalam kursus CC301 - Quantity Measurement. Politeknik Port Dickson.

[49] Zyda, M. (2015). From visual simulation to virtual reality to games. Computer. Perspectives. IEEE Computer Society. September 2015 